\title{
Universiteit
}

Leiden

The Netherlands

\section{Briefing: the pan-sahel initiative}

Ellis, S.

\section{Citation}

Ellis, S. (2004). Briefing: the pan-sahel initiative. African Affairs:

The Journal Of The Royal African Society, 103(412), 459-464.

Retrieved from https://hdl.handle.net/1887/9538

Version: $\quad$ Not Applicable (or Unknown)

License: $\quad$ Leiden University Non-exclusive license

Downloaded from: $\quad$ https://hdl.handle.net/1887/9538

Note: To cite this publication please use the final published version (if applicable). 


\title{
BRIEFING: THE PAN-SAHEL INITIATIVE
}

\author{
STEPHEN ELLIS
}

Those DENIZENS OF WASHINGTON SOMETIMES DESCRIBED AS STRATEGISTS, policy-wonks and Beltway insiders are, most unusually, developing a keen interest in West Africa. Part of the reason is oil. ${ }^{1}$ Another part is the conviction that Africa is a key new front in the war on terrorism. ${ }^{2}$ Regarding the latter, the main threat is perceived to exist in the Horn (where Somalia offers an unhealthy mix of lawlessness, Islam and unpleasant memories of an earlier US failure) and East Africa (scene of terrorist attacks on US embassies in 1998 and of attacks on Israeli targets in 2002). Within the US Department of Defense, the Horn of Africa is the fief of Central Command (CENTCOM), the structure headquartered in Tampa, Florida, that covers the Middle East, including Iraq and Afghanistan. The rest of Africa, meanwhile, falls under the European Command (EUCOM), whose headquarters in Stuttgart, Germany, oversee US military activity in 93 countries involving some 120,000 troops. Hence, it is EUCOM that has responsibility for fighting the war on terrorism in North and West Africa and in the space between, the Sahara desert. Key to this is the Pan-Sahel Initiative (PSI).

PSI first came to public attention in November 2002, when the State Department issued a press release announcing that two officials from the Office of Counterterrorism had visited Chad, Mali, Mauritania and Niger to discuss with officials there a scheme that would be aimed at fighting terrorism, controlling illicit trade and enhancing regional security. Subsequently, little was heard of the scheme until November 2003, when PSI began implementation. Funded by the State Department to the tune of $\$ 7.75$ million, including $\$ 6.5$ million in fiscal year 2004 - small change in Washington, but a substantial amount for such poor countries as those of the Sahel - the heart of PSI consists of training military units from the four partner countries, mostly by soldiers from US Special Forces from EUCOM. Also involved in some aspects of the scheme are US marines, with some logistical work being sub-contracted to the private security company Pacific Architects and Engineers (PAE), well known from peacekeeping operations in Liberia and Sierra Leone in the 1990s.

It is notable that since PSI got going in 2003, US participants increasingly describe it as a means of actually tracking down suspected or known

Stephen Ellis is co-editor of African Affairs. He is grateful to Morolake Akinkugbe for assistance with documentation.

1. Stephen Ellis, 'Briefing: West Africa and its oil', African Affairs 102, 406 (2003), pp. 135-8.

2. See Princeton N. Lyman and J. Stephen Morrison, 'The terrorist threat in Africa', Foreign Affairs 83, 1 (2004), pp. 75-86. 
terrorists. ${ }^{3}$ General Jeff Kohler, head of planning at EUCOM, has expressed a concern that Islamic radicals driven out of Afghanistan could find a new safe haven in the Sahara - in effect a vast ungoverned area stretching eastwards from the Atlantic coast. Northern Mali alone is 'a region the size of Texas', the US ambassador to Mali has pointed out, that is really 'a no man's land'. 'We're helping to teach them [the Malian military] how to control this area themselves so they can keep it from being used by terrorists. ${ }^{4}$

Three factors in particular appear to be driving the fear that the countries of the Sahel could be used by Islamic radicals to create a safe haven where they could train new recruits, as was done in Afghanistan under Taliban rule. First, Algeria is well known to have experienced its own brand of Islamic terrorism in the 1990s, and there are still groups in existence that have a record of fighting in the name of Islam who could conceivably drift south into the Sahel. Second, it is known that some nationals of Sahelian states did actually pass through the Afghan training camps in the 1990 s, and some of them could possibly return to their countries of origin as bearers of a radical political message and with an experience of terrorist warfare. Third, West Africa contains a large number of Muslims and therefore has the potential for radical Islam. Probably the ultimate fear of US officials is that Islamist radicals could infiltrate into northern Nigeria, which has a long history of home-grown radicalism and has, over the past two decades, seen many violent conflicts that have taken on a confessional form. It is the case that when news of the $9 / 11$ attacks was received in Nigeria, there were spontaneous pro-Bin Laden demonstrations in some towns. $^{5}$

The evolution of the PSI from a training programme into something more closely resembling an anti-terrorist campaign is largely a result of specific experience of the Algerian radical Groupe salafiste pour la prédication et le combat (GSPC - Salafist Group for Preaching and Combat). The GSPC was created in 1996 as a breakaway from the Groupes Islamistes Armés (GIA - Islamist Armed Groups), one of the main parties to the Algerian civil war of the 1990s, and formally instituted in 1998. In February 2003 a GSPC group led by Adberrezak el-Para - the war-name of one Ammari Saïfi, an Algerian army deserter who had emerged as a guerrilla leader in the 1990s - took hostage a party of 32 European tourists in the Sahara. In due course it successfully negotiated the payment of a substantial ransom from the German government, rumoured to have been around $€ 4-5$ million. Some Algerian newspapers have suggested that el-Para's

3. This is based on the author's own interviews with US service personnel as well as visits to official websites.

4. 'Airmen support Pan-Sahel Initiative', EUCOM press release, 17 March 2004.

5. See Umar Habila Dadem Danfulani and Sati U. Fwatshak, 'Briefing: the September 2001 events in Jos, Nigeria', African Affairs 101, 403 (2002), p. 251. 
group has direct relations with emissaries of Osama bin Laden and al-Qaeda, ${ }^{6}$ although there is room for debate about how close such ties really are. One French official responsible for security matters, for example, described the GSPC as 'well on the way to becoming bandits'. ${ }^{7}$ Some analysts believe that the hostage-taking episode may have been manipulated by the Algerian intelligence services, masters in the black arts of disinformation, with a view to gaining the sympathy of the US and the right to purchase non-lethal equipment (notably night-vision equipment) previously denied to them on the grounds of Algeria's poor human rights record. ${ }^{8}$ Algeria's civil war has been far from a relatively straightforward contest between securocrats, on the one hand, and Islamic radicals, on the other, but a hideously complicated contest between rival factions both national and local, in which the battlefield is the population itself.

The increasing US presence in the Sahara since the February 2003 hostage-taking incident includes the use of strategic operating locations inside Algeria (such as at Arak, at a strategic pass in the Sahara mountains). In July 2003, Algeria, Chad, Niger and Nigeria, encouraged by the US, signed a co-operation agreement on counterterrorism, in effect joining both sides of the Sahara in a complex of security arrangements whose architecture is American.

At some point in late 2003 or early 2004, remnants of el-Para's GSPC group, who had released their hostages in return for a ransom, were spotted travelling in four Toyota jeeps probably in northern Mali, and were attacked by Algerian forces. ${ }^{9}$ Later, US forces received information concerning a larger party of GSPC fighters. The Islamists were attacked in northern Chad and their force apparently wiped out in a battle in mid-March 2004, in which 43 GSPC members were killed in an engagement that took place under US command and control. ${ }^{10}$ The attacking force was composed of Chadian and Nigerian forces, according to the State Department's Associate Co-ordinator for Counterterrorism. ${ }^{11}$ The dead GSPC fighters included nationals from several states of the Sahel. Among the weapons in their possession were some that may have come originally from army barracks in Mali and Mauritania - where Islamist sympathizers attempted a coup against President Maaouya Ould Sid'Ahmed Taya in 2003. ${ }^{12}$

6. See, for example, 'Le dernier acte de Abderezak el-Para', Le Quotidien d'Oran, 9 August 2003.

7. Author's interview, 3 April 2004.

8. Mustafa Barth, 'Sand castles in the Sahara: US military basing in Algeria', Review of African Political Economy 30, 98 (2003), pp. 679-85.

9. 'Desert shadows', Africa Confidential 45, 4 (20 February 2004).

10. Another source alleges 49 dead, and also reporrts the death of el-Para: Chérif Ouazani, 'Fin de cavale pour l'émir du désert', feune Afrique L'intélligent, 2259 (25 April-1 May 2004), pp. 32-4.

11. Washington File, 2 April 2004.

12. 'Squeezing Le Para', Africa Confidential 45, 5 (5 March 2004). 
This success is likely both to encourage supporters of US military activity in West Africa and to alarm them, as it provides hard evidence of the existence of Islamic fighters who are able to acquire fresh supplies of weapons and to operate across international borders. Future versions of PSI are likely to be increasingly integrated with US training of West African militaries under the African Contingency Operations Training and Assistance (ACOTA) programme administered by the Department of Defense - the lineal descendant of the African Crisis Response Initiative. ${ }^{13}$ PSI conforms to a vision of US anti-terrorist activity that is being impelled from the very top of the Department of Defense, in which the massive, unwieldy instrument of Cold War-style armed forces is less useful in many contexts than the highly flexible Special Forces or than the US Marine Corps, regarded as the most innovative of the branches of the US armed forces. Insiders point out that EUCOM's commander, General James L. Jones, is himself a Marine officer, a most unusual appointment to a mixed command, and it is assumed that this is intended to encourage a change in EUCOM's own military culture. Other senior EUCOM officers, including the number two General Charles Wald, have recent anti-terrorist experience in Afghanistan and Iraq. The ultimate strategic vision of the Department of Defense is what General Kohler calls a 'family' of established operating locations throughout the region from which to maintain a capacity for surveillance and rapid manoeuvre in combination with local armies that are already accustomed to working with US forces, in a seamless web stretching from the Mediterranean shore to the oil-rich Gulf of Guinea. While there are officially no plans for establishing a major US base in Sao Tomé and Principe, as has been speculated in some Washington publications, ${ }^{14}$ some US officers support this idea. A full-scale base offshore would provide ideal logistical support for the lighter touch of special forces and other operations in mainland Africa.

\section{The danger of backfire}

The conventional view in Washington is that PSI has been a conspicuous success in prohibiting the establishment of an Islamist safe haven in the Sahara, and in preventing the ultimate nightmare of Islamist radicals infiltrating northern Nigeria to create Al-Qaeda-type cells in cities like Sokoto and Kano. However, combating Islamist radicalism principally by such military means seems fraught with danger. In the first instance, the emphasis being given to the war on terrorism in West Africa and the Sahara is clearly creating a possibility of rent-seeking. Just as African governments

13. Paul Omach, 'The African Crisis Response Initiative: domestic politics and convergence of national interests', African Affairs 99, 398 (2000), pp. 73-95.

14. Ellis, 'Briefing: West Africa and its oil'. 
during the Cold War could bid for US financial, military and diplomatic support by depicting themselves as under siege from Marxists, so they can now do the same by claiming that their enemies are radical Islamists. The main beneficiary up to now appears to be the government of Algeria.

While there is no doubt that GSPC leaders like el-Para are veterans of Algeria's own dirty war, the groups in the Sahara are perhaps better described as bandit groups, the latest in a long line of outlaws who have sought refuge in the wastes of the Sahara, rather than as tentacles of a centralized organ of Al-Qaeda. Like everyone else in that inhospitable zone, they live on a combination of smuggling, banditry, tourism and government hand-outs. The central Sahara is a major route for smugglers, the main trade reportedly being the transport of cigarettes into Europe. As with similar smuggling trades, once the infrastructure has been put in place and entrepreneurs have invested capital, the routes can be used for contraband of all types, including people, weapons, or anything else. The US fear that these smuggling routes could be used by terrorist groups to acquire weapons is not misplaced; in practice, however, it has to be weighed against the fact that the most proficient smugglers are themselves in league with border guards and other officials, including in southern Algeria. Hence, an uncritical co-operation with such officials carries the risk of US soldiers being used by one faction against its rivals in a complex politics of smuggling. Moreover, an attempt to interdict all smuggling in such a region has the serious consequence of depriving many non-terrorists of their livelihood, and declaring areas a security zone destroys tourism.

In short, while no one doubts that the GSPC groups are dangerous, and that the smuggling of weapons across the Sahara poses a threat, it seems an exaggeration to declare, as General Wald has done, that 'Although it is not prevalent, there have been indications that al Qaeda is operating'. ${ }^{15}$

Meanwhile, in northern Nigeria - arguably the only part of West Africa where there is clear evidence of a culture of radical Islamist activism - the danger of destabilization seems less likely to come from infiltration by foreign agitators than from local political and social disputes mixed with a global discourse of radicalism transmitted by mass media. The news that US armed forces are active in the region and are directing the killing of Islamists, when broadcast in the context of other news concerning Palestine and Iraq, risks turning essentially Nigerian disputes into a global discourse on Islam and the West, led by the US. At present, the Muslim/Christian clashes for which Nigeria is notorious are mired in local disputes more often than they are rooted in any global ideological discourse.

PSI, and whatever successor programmes or spin-offs it is likely to generate in future, ignores the basic principle of counter-insurgency which

15. Interview with Reuters, Accra, published 29 February 2004. 
stresses that military action should be only a minor component of a larger political strategy. The threat to stability in West Africa comes less from ideologically motivated terrorists than from failed states, a category to which Nigeria could conceivably belong in the not-too-distant future. Lyman and Morrison are correct in listing Africa's fundamental problems as 'economic distress, ethnic and religious fissures, fragile governance, weak democracy, and rampant human rights abuses', ${ }^{16}$ which require a different kind of treatment. Rather than analyzing the threat and then finding an instrument to combat it, Washington seems to have resorted to using what it has most obviously available: its formidable armed forces, deployed with little regard to a coherent political strategy.

16. Lyman and Morrison, 'The terrorist threat', p. 76. 